\title{
Obstructive uropathy associated with myelomonocytic infiltration of the prostate
}

\author{
B Hope-Gill, J R Goepel, R C Collin
}

\begin{abstract}
A 72 year old man was diagnosed with chronic myelomonocytic leukaemia (CMML) according to the FAB group classification. He presented with symptoms of anaemia, urinary frequency, hesitancy, and nocturia. He was later admitted with acute urinary retention and acute renal failure, which resolved with treatment. A transurethral resection of the prostate was performed. Histological examination showed fibromuscular hyperplasia with dense infiltration by myelomonocytes which stained positively with chloroacetate esterase; immunohistochemical staining was positive for lysozyme, CD43, CD45, and CD68. Following treatment with oral etoposide he transformed to acute myeloid leukaemia and eventually died. Myelomonocytic infiltration of the prostate has not been reported before. This case extends the spectrum of disease previously recognised in CMML. (F Clin Pathol 1998;51:340-342)
\end{abstract}

Keywords: chronic myelomonocytic leukaemia; prostate; urinary retention; myelomonocytes

Chronic monomyelocytic leukaemia (CMML) as defined by the FAB group ${ }^{1}$ is classified as a myelodysplastic disorder characterised by a peripheral monocytosis and particular bone marrow features. Cytopenia, hepatosplenomegaly, and lymphadenopathy are common. Skin infiltration and serous effusions are also recognised, and gingival infiltration occasionally occurs, particularly if accompanied by a high peripheral monocytosis $\left(>2.6 \times 10^{9} /\right.$ litre).$^{2-5}$ However, myelomonocytic infiltration of other tissues is not reported.

Chesterfield Royal Hospital, Department of Haematology, Calow, Chesterfield, UK

B Hope-Gill

R C Collin

Royal Hallamshire Hospital, Department of Histopathology, Beechill Road, Sheffield, UK

J R Goepel

Correspondence to: Dr R C Collin, Department of Haematology, Chesterfield Royal Hospital, Calow, Chesterfield S44 5BL, UK.

Accepted for publication 12 November 1997
$1 \mathrm{ng} / \mathrm{ml}$. The blood film and bone smears both showed morphological abnormalities with abnormal dysplastic granulopoiesis.
The bone marrow showed myeloid and monocytic hyperplasia and myeloid precursors were hypogranular. There was no excess of blast cells. Micromegakaryocytes were identified in marrow smears.

In the context of a persistent peripheral blood monocytosis of $>1.0 \times 10^{9} /$ litre, these findings were consistent with a diagnosis of chronic myelomonocytic leukaemia as defined by the FAB criteria. ${ }^{1}$ Elective admission was arranged for a three unit transfusion of packed red cells a few days later.

While awaiting admission he became increasingly lethargic and nauseous. Examination revealed a distended bladder and a smooth, tender, moderately enlarged prostate; when catheterised, $2300 \mathrm{ml}$ of urine were drained. He had not previously experienced any symptoms of urinary obstruction until two weeks before admission. Investigations at this stage revealed $\mathrm{Na} 131 \mathrm{mmol} / \mathrm{litre}, \mathrm{K} 5.9 \mathrm{mmol} /$ litre, $\mathrm{HCO}_{3} 21 \mathrm{mmol} /$ litre, urea $30 \mathrm{mmol} /$ litre, and creatinine $995 \mu \mathrm{mol} /$ litre.

Treatment with intravenous fluids was started and a blood transfusion was given. $\mathrm{He}$ developed postcatheterisation diuresis and his serum biochemistry improved such that the creatinine had fallen to $126 \mu \mathrm{mol} /$ litre two days later. $\mathrm{He}$ was discharged with a urethral catheter in situ to await an elective transurethral resection of the prostate. Subsequently a $30 \mathrm{~g}$ prostate was resected and histological examination revealed dense infiltration with myelomonocytes.

Postoperatively, he required multiple packed red cell and platelet transfusions owing to heavy haematuria.

Subsequently, he was entered into the Medical Research Council CMML trial and randomised to receive oral etoposide (VP-16), 50 $\mathrm{mg}$ /day. However, three months later he was readmitted with rigors, a chest infection, and general deterioration. Full blood count and peripheral film revealed a haemoglobin of 10.8 $\mathrm{g} / \mathrm{dl}$ and a white blood cell count of $137 \times 10^{9} /$ litre (neutrophils 115.5, lymphocytes 0.5, monocytes $16.7,14 \%$ blast cells with large numbers of Auer rods) signifying transformation to acute myeloid leukaemia. His clinical condition deteriorated progressively and in conjunction with the patient and his wife the decision was made to treat palliatively. He died three weeks later at home. No necropsy examination was performed.

\section{Histology report}

Numerous prostate fragments were received fixed in formalin. These showed bladder neck and prostate, with hyperplasia of prostate 


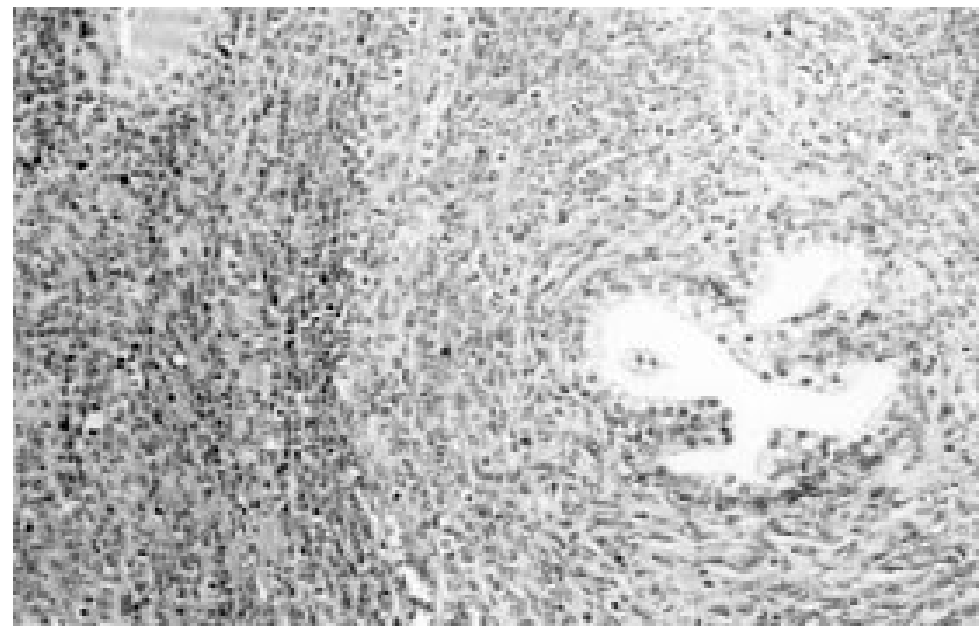

Figure 1 Prostate infiltrated by chronic myelomonocytic leukaemia cells. (Haematoxylin and eosin, $\times 149$.)

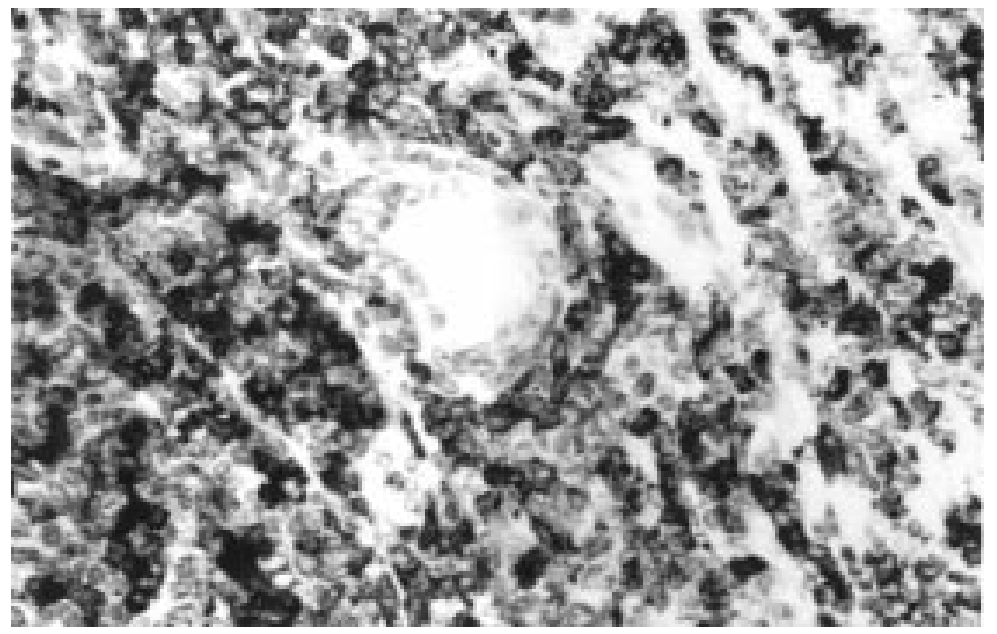

Figure 2 Chronic myelomonocytic leukaemia in prostate. Many cells are positive for CD68. (Immunoperoxidase PGM 1, ×297.)

Table 1 Summary of reported cases of leukaemic infiltration of the prostate gland

\begin{tabular}{lcc}
\hline Leukaemia type & $\begin{array}{l}\text { Cases with } \\
\text { prostatic } \\
\text { histology }\end{array}$ & $\begin{array}{l}\text { Cases with } \\
\text { urinary } \\
\text { retention }\end{array}$ \\
\hline CLL & 24 & 15 \\
Acute granulocytic & 3 & 3 \\
Chronic granulocytic & 2 & 2 \\
Chronic myelomonocytic (present & 1 & 1 \\
$\quad$ case) & 22 & \\
Cases with no prostatic histology & 22 \\
\hline
\end{tabular}

glands and particularly of the fibromuscular stroma. Prostatic stromal elements were infiltrated by dense masses and cords of cells (fig 1). These were of medium size with slight pleomorphism. The nucleus was ovoid to rounded and vesicular cytoplasm varied in extent; in some it was granular. Chloroacetate esterase staining was positive in many of these cells. Immunohistochemical staining was positive in most cells for lysozyme, in many for CD43 and CD45, and in many for CD68 (fig 2).

\section{Discussion}

Case reports concerning leukaemic infiltration of the prostate are uncommon. Dajani and Burke reviewed 57 cases $^{6}$ and we have found four more cases in other published reports ${ }^{7-9}$ (table 1). The majority presented with the onset of or worsening of symptoms of urinary outflow obstruction. The best documented and most recent cases occurred with chronic lymphocytic leukaemia, in which 20 cases of 29 presented with acute urinary retention; subsequent investigation and treatment of this revealed leukaemic infiltration of the prostate.

A necropsy study of 503 leukaemic patients showed that the actual incidence of metastases to the prostate is higher than the number of case reports would suggest. ${ }^{10}$ Necropsy revealed up to $40 \%$ prostatic infiltration in acute lymphoblastic leukaemia (ALL), $11-20 \%$ in chronic lymphocytic leukaemia (CLL), 11$20 \%$ in acute myeloblastic leukaemia (AML), and between $1 \%$ and $10 \%$ in chronic myelocytic leukaemia (CML). ${ }^{10}$ These frequencies reflect the tendencies of the different leukaemias to metastasise to non-reticuloendothelial tissues. The discrepancy between the frequency of case reports and incidence of prostatic involvement found at necropsy reflects the fact that unless urinary symptoms develop prostatic involvement is unlikely to be detected.

The extent to which the leukaemic infiltrate contributes to urinary obstruction is unknown. The best documented cases of CLL infiltration of the prostate associated with urinary retention were combined with histological evidence of benign prostatic hypertrophy or with bladder trabeculation, suggesting chronic obstruction. Certainly others suggest that the presence of benign prostatic hypertrophy is necessary to precipitate retention, and not all cases with leukaemic infiltration of the prostate develop obstructive symptoms. ${ }^{6}$ Cases of acute retention in acute leukaemia may be explained by other mechanisms, such as leukaemic meningitis.

Patients present with typical symptoms of urinary outflow obstruction. ${ }^{6-9}$ The prostate is uniformly enlarged and smooth, as in benign prostatic hypertrophy. In CLL, lymphocytic infiltration is irregular in distribution, so that preoperative needle biopsy is unreliable. There are insufficient published data to show whether this is also true for granulocytic leukaemias. It has been suggested that patients who present with acute granulocytic leukaemia and urinary retention tolerate surgical transurethral resection of the prostate for alleviation of symptoms less well than patients with CLL, in whom the five year survival is good. ${ }^{6}$ Therefore, where the diagnosis is known in advance, preoperative prostatic needle biopsy is warranted in these patients and other treatment options should be considered. This patient responded to surgical transurethral resection of the prostate and he subsequently died after transformation to AML.

Dajani and Burke reported five previous cases of granulocytic leukaemia (table 1) causing urinary retention. ${ }^{6}$ However, precise defined subtyping of the granulocytic infiltrate is lacking. We were unable to find a conclusive report in the English language literature of myelomonocytic infiltration of the prostate more recently than 1982, when the diagnostic criteria for CMML were defined by the FAB 
group. This illustrates the highly unusual nature of this particular case.

Interestingly, bladder outlet obstructive symptoms developed while the peripheral monocyte count was lower than $2.6 \times 10^{9} /$ litremonocytosis greater than this is associated with non-reticuloendothelial tissue infiltration. ${ }^{2}$ Eleven of 12 cases of myelomonocytic skin infiltration occurred with a high peripheral myelomonocyte count. ${ }^{211} 12$ None of the published reviews has addressed tissue infiltration by monocytes other than in the sites previously mentioned, which may be because the possibility has not been recognised. This case shows that the spectrum of disease seen in CMML is wider than has been appreciated and lends support to the premise that the peripheral monocyte count is not a wholly reliable indicator of clinical disease.

1 Bennet HM, Catovsky D, Daniel MT, et al. The FrenchAmerican-British Co-operative Group. Proposals for the
classification of the myelodysplastic syndromes. $\mathrm{Br} f$ Classification of the myel $1982 ; 51: 189-99$.
2 Worseley A, Oscier DG, Stevens J, et al. Prognostic features of CMML: a modified Bournemouth score gives the best of CMML: a modified Bournemouth score gives the

3 Sakal-Celiquy P, Desaint B, Herrera A, et al. Chronic myelomonocytic leukaemia according to the $\mathrm{FAB}$ classification: analysis of 35 cases. Blood 1984;63:634-8.

4 Allessandrino EP, Orlandi E, Brusamolino E, et al. Chronic myelomonocytic leukaemia: clinical features, cytogenetics and prognosis in 30 consecutive cases. Haematol Oncol 1985;3:147-55.

5 Fénaux P, Jouet JP, Zandecki M, et al. Chronic and subacute myelomonocytic leukaemia in the adult: a report of 60 cases with special reference to prognostic factors. $\mathrm{Br} \mathcal{f} \mathrm{Hae}$ matol 1987;65:101-6.

6 Dajain YF, Burke M. Leukaemic infiltration of the prostate. Cancer 1976;38:2442-6.

7 Singh G, Murray K. Lymphocytic infiltration of the prostate presenting as retention. Urologia Internationalis 1994;53: $225-6$.

8 Belhiba H, Casse C, Katmeh S, Bourdon J. Prostatic involvement in leukaemia. Report of a case. Progres en Urologie 1992;2:650-2.

9 Merinsky E, Baratz M, Kahu Y. Leukaemic infiltration of the prostate. Br f Urol 1981;53:150-1.

10 Viadana E, Bross IDJ, Pickren JW. An autopsy study of the metastatic patterns of human leukaemia. Oncology 1978;35: 87-96.

11 Duguid JKM, Mackiers J, McVerry A. Skin infiltration associated with chronic myelomonocytic leukaemia. $\mathrm{Br} f$ Haematol 1983;65:101-6.

12 Copplestone JA, Oscier DG, Mufti GJ, Hamblin TJ. Monocytic skin infiltration in CMML. Clin Lab Haematol $1986 ; 8: 115-19$. 